\title{
Factors Affecting Influenza Vaccination Rates among Patients with Chronic Obstructive Pulmonary Disease in Rize, Turkey
}

Songül Özyurt, Bilge Yılmaz Kara, Neslihan Özçelik, Ünal Şahin

Department of Pulmonology, Recep Tayyip Erdoğan University School of Medicine, Rize, Turkey

Cite this article as: Özyurt S, Yılmaz Kara B, Özçelik N, Şahin Ü. Factors Affecting Influenza Vaccination Rates among Patients with Chronic Obstructive Pulmonary Disease in Rize, Turkey. Turk Thorac J 2018; 19(3): 122-6.

Abstract OBJECTIVES: Acute exacerbations of chronic obstructive pulmonary disease (AECOPD) are major components of COPD-related socioeconomic burden. Upper or lower respiratory tract infections, usually caused by respiratory viruses or bacteria, are common causes of AECOPD. Vaccination aganist influenza virus and Streptoccus pneumoniae, the most prevalent agents, is recommended by COPD guidelines. The aims of this study were to determine the factors affecting vaccination among patients with COPD and to assess the effect of vaccination status on AECOPD.

MATERIALS AND METHODS: Patients with COPD were recruited from the outpatient clinic of a tertiary hospital between December 2014 and January 2015. Demographic data, vaccination status, and COPD-related hospital admissions triggered by tracheobronchial infections were evaluated.

RESULTS: In total, 108 patients were enrolled; 102 (94\%) subjects were male, and 6 (6\%) subjects were female; the mean age was 65.6 years. The number of patients who had received pneumococcal and influenza vaccinations were $8(0.07 \%)$ and $36(33.3 \%)$, respectively. There was no significant correlation between the level of education and vaccination status. No significant difference was found between two groups in terms of exacerbation frequency, hospitalization rates, mMRC scores, and COPD stages.

CONCLUSION: More efforts by both physicians and patients are needed to reach the ideal rates of vaccination for COPD.

KEYWORDS: Chronic obstructive pulmonary disease, influenza vaccination, pneumococcal vaccination

Received: 26.09 .2017

Accepted: 30.01 .2018

Available Online Date: 12.06.2018

\section{INTRODUCTION}

Chronic obstructive pulmonary disease (COPD) represents a major health challenge and is currently the fourth leading cause of death worldwide [1]. Acute excacerbations are the most common causes of death in COPD patients. . The connection between acute exacerbations of COPD (AECOPD) and morbidity and mortality has been disclosed [2]. Latest therapeutic and protective strategies are directed towards the prevention of AECOPD.

Approximately $70 \%$ of AECOPD cases are of infectious origin. Respiratory viruses are isolated in approximately $30 \%$ of cases $[3,4]$. Bacterial and viral co-infections may also occur with bacterial infections complicating an initial viral infection. Both severity of COPD and not receiving influenza vaccination have been shown to be associated with a high risk of mortality [5]. As a result, influenza and pneumococcal infections are the most common causes of AECOPD [6]. Both influenza and pneumococcal vaccinations have been reported to decrease the incidence of lower respiratory tract infections in the GOLD (Global Initiative for Chronic Obstructive Pulmonary Disease) 2017 guideline [7]. For this reason, vaccination is a cost-effective and life-saving approach. There are few studies that investigated the effects of influenza vaccination on AECOPD, but they have shown that influenza vaccination results in lower number of exacerbations than placebo use in vaccination [8]. No statistically significant effects on exacerbation have been shown with pneumococcal vaccination [9].

In this study, we aimed to assess the characteristics of COPD patients during 2014 vaccination season and its association with AECOPD in the following year in Rize, Turkey.

Address for Correspondence: Bilge Yılmaz Kara, Department of Pulmonology, Recep Tayyip Erdoğan University School of Medicine, Rize, Turkey

E-mail: drbilgeyilmaz@hotmail.com 


\section{MATERIALS AND METHODS}

\section{Study Population}

A total of 108 patients with COPD were recruited from the outpatient clinic of a tertiary center in Rize province, Turkey, between December 2014 and January 2015. All patients were residents of Rize, and they had been followed by pulmonary specialists for COPD.

\section{Study Design}

Educational status, residence information (urban/rural area), mMRC (modified Medical Research Council) dyspnea score and COPD stage according to GOLD guidelines, smoking habits, and co-morbidities were noted with the help of a questionnaire. History of an influenza vaccine shot during the previous year or a pneumococcal vaccine shot during the last five years, factors affecting the decision of being vaccinated or not (the source of information if vaccinated, the reason if not vaccinated), and the number of severe or mild AECOPD cases requiring hospital admission were enquired and confirmed using the hospital's computer recording system.

Table 1. Demographic data of all patients and study results

\begin{tabular}{|c|c|c|}
\hline \multirow{2}{*}{$\begin{array}{l}\text { Parameters } \\
\text { Mean age }\end{array}$} & \multicolumn{2}{|c|}{ All patients $(n=108)$} \\
\hline & (Years) & $65.6 \pm 9.7$ \\
\hline Gender & $(\mathrm{M} / \mathrm{F})$ & $102(94 \%) / 6(6 \%)$ \\
\hline Place of residence & (Urban/Rural) & $68(63 \%) / 40(37 \%)$ \\
\hline \multirow[t]{5}{*}{ Education level } & Illiterate & $14(13 \%)$ \\
\hline & Elementary school & $70(64.8 \%)$ \\
\hline & Junior high school & $10(9.3 \%)$ \\
\hline & High school & $7(6.5 \%)$ \\
\hline & University & $1(0.9 \%)$ \\
\hline GOLD Stages & $\mathrm{A} / \mathrm{B} / \mathrm{C} / \mathrm{D}$ & $\begin{array}{l}36(33.3 \%) / \\
24(22.2 \%) / \\
19(17.6 \%) / \\
29(26.9 \%)\end{array}$ \\
\hline Smoking history & (packs/year) & $48.5 \pm 31.6$ \\
\hline \multirow[t]{2}{*}{ Influenza vaccination } & Vaccinated & $36(33.4 \%)$ \\
\hline & Non-vaccinated & $72(66.6 \%)$ \\
\hline \multirow[t]{2}{*}{$\begin{array}{l}\text { Pneumococcal } \\
\text { vaccination }\end{array}$} & Vaccinated & $8(0.07 \%)$ \\
\hline & Non-vaccinated & $100(99.3 \%)$ \\
\hline \multirow[t]{3}{*}{$\begin{array}{l}\text { Source recommending } \\
\text { vaccination }\end{array}$} & Physician & $33(82.5 \%)$ \\
\hline & Pharmacist & $6(15 \%)$ \\
\hline & $\begin{array}{l}\text { Other } \\
\text { (TV, newspaper etc.) }\end{array}$ & $1(2.5 \%)$ \\
\hline \multirow[t]{2}{*}{$\begin{array}{l}\text { Reason for not } \\
\text { being vaccinated }\end{array}$} & Not recommended & $61(88.4 \%)$ \\
\hline & $\begin{array}{l}\text { Do not believe } \\
\text { in the benefit }\end{array}$ & $6(8.7 \%)$ \\
\hline
\end{tabular}

M: male; F: female; GOLD: Global Initiative for Chronic Obstructive Pulmonary Disease; TV: television. Data were presented as number and percentage.

\section{Exclusion Criteria}

Patients previously diagnosed with obstructive pathologies such as asthma or bronchiectasis; patients with active cancer, chronic organ failure, uncontrolled hypertension, or diabetes mellitus; patients with a history of hospitalization during the study period, suffering from AECOPD, or unable to perform a pulmonary function test (PFT) for any reason during the data collection phase were excluded from the study. All patients provided written informed consent. The study was approved by the local ethics committee and was conducted in accordance with the Declaration of Helsinki.

\section{Statistical Analysis}

The primary objective of the study was to determine the factors affecting influenza and pneumococcal vaccination among patients with COPD, and the secondary objective of the study was to show the relationship between vaccination and AECOPD rates in the following year.

IBM Statistical package for Social Sciences version 21.0 (IBM SPSS Corp.; Armonk, NY, USA) software was used for statistical analysis. Parametric data were presented as mean \pm standard deviation. Student's t-test was used for parametric variables, and the Mann-Whitney U-test was used for nonparametric variables. Spearman test was used for correlation analysis. Yates correction chi-square test and Fisher's exact test were used for the comparison of qualitative data. P-values less than 0.05 were considered significant.

\section{RESULTS}

A total of 108 patients were included in the study. Their mean age was $65.6 \pm 9.7$ years, and $94 \%$ were male. Among them, $63 \%$ resided in urban areas and the remaining $37 \%$ resided in rural areas. In addition to COPD, systemic hypertension was seen in $64.8 \%$ of the patients, congestive heart failure in $12 \%$, and diabetes mellitus in $12 \%$. According to the GOLD guideline, $33.3 \%$ of the patients were in group $\mathrm{A}, 22.2 \%$ were in group $\mathrm{B}, 17.6 \%$ were in group $\mathrm{C}$, and $26.9 \%$ were in group $\mathrm{D}$. The mean smoking rate was $48.5 \pm 31.6$ packs per year. In total, $13 \%$ of the patients were illiterate, $64.8 \%$ were elementary school graduates, $9.3 \%$ were junior high school graduates, $6.5 \%$ were high school pass-outs, and $0.9 \%$ was university graduates. In the study population, only eight (7\%) patients had pneumococcal vaccine shots and 36 (33.4\%) had influenza vaccine shots. Vaccination was recommended by physicians in $82.5 \%$ of the patients, by pharmacists in $15 \%$, and by other sources (e.g., television or newspaper) in $2.5 \%$. Among patients who did not receive vaccinations, $8.7 \%$ did not believe that vaccination was beneficial, whereas $88.4 \%$ reported that they did not receive vaccination because it was not recommended by their physician (Table 1).

Demographic data comparing the influenza-vaccinated and non-vaccinated groups are presented in Table 2. Thirty-six of 108 patients $(33.3 \%)$ had received influenza vaccination. There was no statistically significant difference between groups of patients who had and had not been vaccinated in terms of age, gender, co-morbidities, COPD stages, or smoking status. The rate of influenza vaccination was significantly higher in patients living in urban areas compared to those living in rural areas $(p=0.024)$. 


\begin{tabular}{|c|c|c|c|}
\hline Parameters & $\begin{array}{l}\text { Influenza- } \\
\text { vaccinated } \\
\quad(n=36)\end{array}$ & $\begin{array}{c}\text { Non- } \\
\text { vaccinated } \\
(n=72)\end{array}$ & p \\
\hline Age (years) & $65.9 \pm 11.0$ & $65.5 \pm 9.1$ & 0.60 \\
\hline Gender (M/F) & $\begin{array}{c}34(31 \%) / \\
2(1 \%)\end{array}$ & $\begin{array}{c}68(63 \%) / \\
4(3 \%)\end{array}$ & 0.98 \\
\hline Urban/Rural Residents & $\begin{array}{c}28(77.8 \%) / \\
8(22.2 \%)\end{array}$ & $\begin{array}{l}40(55.5 \%) / \\
32(44.5 \%)\end{array}$ & 0.024 \\
\hline COPD Stages (A/B/C/D) & $9 / 6 / 9 / 12$ & $27 / 18 / 10 / 17$ & 0.22 \\
\hline Co-morbidity (n, \%) & $14(38.8 \%)$ & $32(44.4 \%)$ & 0.68 \\
\hline Education level & & & 0.29 \\
\hline - Illiterate & $2(5.6 \%)$ & $12(16.6 \%)$ & \\
\hline - Elementary school & $28(77.8 \%)$ & $48(66.7 \%)$ & \\
\hline - Junior high school & $4(11 \%)$ & $6(8.3 \%)$ & \\
\hline - High school & $1(2.8 \%)$ & $6(8.3 \%)$ & \\
\hline - University & $1(2.8 \%)$ & $0(0 \%)$ & \\
\hline Non-smoker (n, \%) & $2(5.5 \%)$ & $5(7 \%)$ & \\
\hline Smoker (n, \%) & $2(5.5 \%)$ & $9(12.5 \%)$ & 0.49 \\
\hline Ex-smoker (n, \%) & $32(89 \%)$ & $58(80.5 \%)$ & \\
\hline Smoking rate (packs/year) & $47.15 \pm 33.0$ & $51.19 \pm 28.9$ & 0.27 \\
\hline Biomass (n, \%) & $1(2.7 \%)$ & $4(5.5 \%)$ & 0.66 \\
\hline $\begin{array}{l}\text { Pneumococcal } \\
\text { vaccination }(n, \%)\end{array}$ & $5(13.8 \%)$ & $3(4.1 \%)$ & 0.11 \\
\hline
\end{tabular}

Table 3. PFT results, mMRC scores, exacerbation numbers, and hospitalization rates of influenza-vaccinated and nonvaccinated patients

\begin{tabular}{|c|c|c|c|}
\hline Parameters & $\begin{array}{l}\text { Influenza- } \\
\text { vaccinated } \\
(\mathrm{n}=36)\end{array}$ & $\begin{array}{l}\text { Non- } \\
\text { vaccinated } \\
(n=72)\end{array}$ & $p$ \\
\hline $\mathrm{FEV}_{1}(\%$ pred $)$ & $51.9 \pm 15.9$ & $62.6 \pm 23.1$ & 0.02 \\
\hline FVC (\% pred) & $67.1 \pm 16.9$ & $76.7 \pm 20.7$ & 0.01 \\
\hline $\mathrm{FEV}_{1} / \mathrm{FVC}(\%)$ & $58.8 \pm 8.5$ & $62.3 \pm 10.3$ & 0.02 \\
\hline $\mathrm{mMRC}$ score & $2.1 \pm 1.1$ & $1.8 \pm 1.0$ & 0.78 \\
\hline Number of exacerbations & $\begin{array}{c}5.5 \pm 5.8 \\
\text { Median: } 4\end{array}$ & $\begin{array}{c}5.1 \pm 4.7 \\
\text { Median: } 4\end{array}$ & 0.89 \\
\hline Number of hospitalizations & $0.9 \pm 1.9$ & $0.8 \pm 2.0$ & 0.25 \\
\hline \multicolumn{4}{|c|}{$\begin{array}{l}\text { M: male; } F \text { : female; } F E V_{1} \text { : forced expiratory volume in } 1 \mathrm{~s} ; \mathrm{FVC} \text { : } \\
\text { forced vital capacity; mMRC: modified Medical Research Council; \% } \\
\text { pred: \%predicted } \\
\text { Data were presented as number and percentage. }\end{array}$} \\
\hline
\end{tabular}

Influenza-vaccinated patients had significantly lower postbronchodilator $\mathrm{FEV}_{1}, \mathrm{FEV}_{1} / \mathrm{FVC}$, and FVC values than nonvaccinated patients. No statistically significant difference was found between two groups in terms of frequency of exacerbations, rates of hospitalization, and mMRC scores (Table 3).

The rate of hospitalization positively correlated with GOLD stages, exacerbation number, and $\mathrm{mMRC}$ score and negatively correlated with pre- and post-bronchodilator FEV 1 (liters, \%)
Table 4. Correlation analysis of hospitalization rates and GOLD stages, vaccination, exacerbation number, PFT parameters, and $\mathrm{mMRC}$ scores

\begin{tabular}{|c|c|c|}
\hline Hospitalizations & $\mathbf{r}$ & $\mathbf{p}$ \\
\hline GOLD stages & +0.536 & $<0.001$ \\
\hline Influenza vaccination & +0.111 & 0.252 \\
\hline Pneumococcal vaccination & +0.124 & 0.203 \\
\hline Number of exacerbations & +0.467 & $<0.001$ \\
\hline Pre-FEV ${ }_{1} / F V C$ ratio & -0.128 & 0.199 \\
\hline Pre-FEV 1 (L) & -0.464 & $<0.001$ \\
\hline Pre-FEV $_{1}(\%)$ & -0.420 & $<0.001$ \\
\hline Pre-FVC (L) & -0.433 & $<0.001$ \\
\hline Pre-FVC (\%) & -0.449 & $<0.001$ \\
\hline Post-FEV $/$ /FVC ratio & -0.212 & 0.032 \\
\hline Post-FEV $_{1}(\mathrm{~L})$ & -0.438 & $<0.001$ \\
\hline Post-FEV $1 \%$ (\%) & -0.449 & $<0.001$ \\
\hline Post-FVC (L) & -0.406 & $<0.001$ \\
\hline Post-FVC (\%) & -0.459 & $<0.001$ \\
\hline $\mathrm{mMRC}$ score & +0.575 & $<0.001$ \\
\hline
\end{tabular}

and FVC (liters, \%). There was no correlation between rates of hospitalization and vaccination as well as pre- and postbronchodilator $\mathrm{FEV}_{1} / \mathrm{FVC}$ ratios (Table 4 ).

\section{DISCUSSION}

Although there is evidence that viral infections lead to exacerbations of chronic airway diseases such as COPD [10,11], vaccination has not been proven to reduce mortality[12]. On the other hand, a systematic review that summarized the immunogenicity, safety, efficacy, and effectiveness of influenza vaccination in patients with COPD found that six of seven studies indicated long-term benefits such as decreased number of exacerbations, reduced number of hospitalizations, and decreased rates of all-cause and respiratory mortality [13]. In our study, we were not able to show the reduced number of exacerbations or rates of hospitalization in vaccinated patients. Another study investigating etiologic agents causing AECOPD found Haemophilus influenzae, Moraxella catarhalis, and rhinovirus as the most incident pathogens. Therefore, the vaccination spectrum for COPD should be more diverse to enclose other potential pathogens causing AECOPD [14], and new vaccines against these pathogens should be developed.

Educational status may influence vaccination awareness; in a study investigating the relationship between education level and preventive health care use, college attendance was found to be strongly associated with receiving influenza vaccination in old age [15]. On the contrary, another study concluded that receiving vaccination was not related to the level of education but that the advice of health care professionals (particularly a doctor) led to high vaccination compliance [16]. Our findings showed that there was no relationship be- 
tween the level of education and status for vaccination. The explanation of these conflicting results is that the relationship might be more complex and cannot be directly explained by the level of education or source of advice.

Patients tend to act in the direction of their physician's suggestion, particularly when they have a chronic illness, which frequently exacerbates and forces the patients to seek a specialist's help. Most doctors have a tendency to closely deal with patients with advanced disease and frequent hospitalizations. Compared with mild disease, patients with more advanced disease stage may be more likely to seek vaccination because the consequences of influenza are more severe in such cases [17]. In our study, the negative correlation between PFT results and vaccination rates may reveal that "patients in danger" are those in an advanced stage based on doctors' perspectives; PFT is not the only, but is still the best, indicator of severity. Further, the positive correlation with the mMRC score supports the idea that these patients suffer from more advanced disease. However, a change introduced in the 2010 NICE guideline is the new grading of COPD severity, which is not based on the PFT alone. A full clinical assessment should include the severity of symptoms, frequency of exacerbations, and impact of disease on the functional and health status. All patients, regardless of their disease stage, should be recommended to receive influenza and pneumococcal vaccinations, body composition management, and pulmonary rehabilitation in addition to pharmacotherapy [18]. In our study, COPD staging was done according to the latest GOLD guidelines, but no statistically significant difference between groups was demonstrated in terms of exacerbation frequency or hospitalization rates.

Although Rize is a low-income province in Turkey, vaccination is paid by the health care system; hence, we do not believe that financial constrains are responsible for the low rate of vaccination in patients with COPD. Therefore, better understanding of factors affecting low compliance with vaccination at the individual level is crucial and should be elucidated in future studies [19].

In our study, low rates of both influenza and pneumococcal vaccinations in patients with COPD have been elucidated in Rize province. Similar studies have estimated vaccination rates from other parts of Turkey. Aktürk et al. reported a rate of $36.5 \%$ for influenza vaccination and $14.1 \%$ for pneumococcal vaccination [20]. A study investigating the gaps in using influenza vaccine pointed out that health care workers in lowincome countries, such as India, believed that the influenza vaccine was harmful and hence was not prescribed. Other reasons cited by 1359 participants included unawareness about vaccine availability (32\%), doubts about efficacy (18\%), busy schedule $(12 \%)$, fear of side effects $(4 \%)$, and patients' disbelief of being at risk group of influenza disease (6\%) [21].

These results may be due to the lower vaccination rates in patients with COPD in Rize province than in similar subject groups in which a retrospective study design is used [22]. Moreover, beside the vaccination rates, other factors such as inhaler/systemic steroid usage, bacterial colonization of the lower respiratory tract, and antibiotic usage may be related with the AECOPD frequency. In this regard, there is a need for prospective, randomized controlled trials involving more subjects.

The limitations of our study were as follows: 1. A comparison between males and females was not possible because most patients were male. 2 . The sample size was small; therefore, the number of vaccinated subjects was not adequate to make a final decision about the effectiveness of vaccination. 3 . Bacteriologic or viral isolation of agents responsible for AECOPD was not possible due to financial or technical causes. 4. Since the number of pneumococcal vaccine recipients was low, the relevant data have not been discussed. 5. Data is missing about why doctors avoid prescription of pneumococcal or influenza vaccines.

In conclusion, tracheobronchial infections are one of the most common causes of acute attacks in patients with COPD, and vaccination against existing pathogens is essential. However, vaccination rates are still low, and it should be emphasized by physicians that all patients should be vaccinated.

Ethics Committee Approval: Ethics committee approval was obtained for this study from the Ethics Committee of Karadeniz Technical University. (Approval Number: 2014/135)

Informed Consent: Written informed consent was obtained from all patients who participated in this study.

Peer-review: Externally peer-reviewed.

Author contributions: Concept - S.Ö., Ü.Ş.; Design - S.Ö., Ü.Ş.; Supervision - S.Ö., Ü.Ş.; Resource - S.Ö., Ü.Ş. Materials - S.Ö., Ü.Ş.; Data Collection and/or Processing - S.Ö.; Analysis and/or Interpretation B.Y.K., N.Ö.; Literature Search - B.Y.K.; Writing - B.Y.K., N.Ö.; Critical Reviews - B.Y.K., N.Ö.

Conflict of Interest: The authors have no conflicts of interest to declare.

Financial Disclosure: The authors declared that this study has received no financial support.

\section{REFERENCES}

1. Lozano R, Naghavi M, Foreman K, et al. Global and regional mortality from 235 causes of death for 20 age groups in 1990 and 2010: a systematic analysis for the Global Burden of Disease Study 2010. Lancet 2012;380:2095-128. [CrossRef]

2. García-Sanz MT, Cánive-Gómez JC, Senín-Rial L,et al. Oneyear and long-term mortality in patients hospitalized for chronic obstructive pulmonary disease. J Thorac Dis 2017;9:636-45. [CrossRef]

3. Miravitlles M, Anzueto A. Role of infection in exacerbations of chronic obstructive pulmonary disease. Curr Opin Pulm Med. 2015;21:278-83. [CrossRef]

4. Mohan A, Chandra S, Agarwal D, et al. Prevalence of viral infection detected by PCR and RT-PCR in patients with acute exacerbation of COPD: a systematic review. Respirology 2010;15:53642. [CrossRef]

5. Montserrat-Capdevila J, Godoy P, et al. [Risk factors for mortality in patients with chronic obstructive pulmonary disease]. Aten Primaria 2015;47:498-504. [Article in Spanish] [CrossRef]

6. Sethi S. Murphy T. Infection in the pathogenesis and course of chronic obstructive pulmonary disease. $N$ Engl J Med 2008;359:2355-65. [CrossRef] 
7. GOLD (2017) Global Strategy for the Diagnosis, Management, and Prevention of Chronic Obstructive Pulmonary Disease. February. Available at: http://www.goldcopd.org.

8. Poole PJ, Chacko E, Wood-Baker R, et al. Influenza vaccine for patients with chronic obstructive pulmonary disease. Cochrane Database Syst Rev 2006;1:CD002733. [CrossRef]

9. Walters JA, Smith S, Poole P,et al. Injectable vaccines for preventing pneumococcal infection in patients with chronic obstructive pulmonary disease. Cochrane Database Syst Rev 2010;11:CD001390. [CrossRef]

10. Hershenson MB. Rhinovirus-Induced Exacerbations of Asthma and COPD, Scientifica (Cairo) 2013;2013:405876.

11. Koul PA., Khan UH., Asad R, et al. Contribution of influenza to acute exacerbations of chronic obstructive pulmonary disease in Kashmir, India, 2010-2012. Influenza Other Respir Viruses 2015;9:40-2. [CrossRef]

12. Joshi M, Chandra D, Mittadodla P, et al. The Impact of Vaccination on Influenza-Related Respiratory Failure and Mortality in Hospitalized Elderly Patients Over the 2013-2014 Season. Open Respir Med J 2015;9:9-14. [CrossRef]

13. Bekkat-Berkani R, Wilkinson T, Buchy $P$, et al. Seasonal influenza vaccination in patients with COPD: a systematic literature review. BMC Pulm Med 2017;17:79. [CrossRef]

14. Wilkinson TMA, Aris E, Bourne $S$, et al. A prospective, observational cohort study of the seasonal dynamics of airway pathogens in the aetiology of exacerbations in COPD. Thorax 2017;72:919-27. [CrossRef]
15. Fletcher JM, Frisvold DE. Higher Education and Health Investments: Does More Schooling Affect Preventive Health Care Use? J Hum Cap 2009 Summer; 3:144-76. [CrossRef]

16. Cimen P, Unlu M, Kirakli C, et al. Should Patients With COPD Be Vaccinated? Respir Care 2015;60:239-243. [CrossRef]

17. Mullahy J. It'Il only hurt a second? Microeconomic determinants of who gets flu shots. Health Econ 1999;8:9-24.

18. Walker PP. Opportunistic case finding pivotal in diagnosing COPD. Practitioner 2010;254:19-20,23-4,2.

19. Gnatiuc L,Buist AS, Kato B, Janson C, Ait-Khaled NA, Nielsen R, et al. Gaps in using bronchodilators, inhaled corticosteroids and influenza vaccine among 23 high- and low-income sites. Int J Tuberc Lung Dis 2015;19:21-30. [CrossRef]

20. Aka Aktürk Ü, Görek Dilektaşlı A, Şengül A, Musaffa Salepçi B, Oktay N, Düger M, et al. Influenza and Pneumonia Vaccination Rates and Factors Affecting Vaccination among Patients with Chronic Obstructive Pulmonary Disease. Balkan Med J 2017;34:206-11. [CrossRef]

21. Bali NK, Ashraf M, Ahmad F, Khan UH, Widdowson MA, Lal $\mathrm{RB}$, et al. Knowledge, attitude, and practices about the seasonal influenza vaccination among healthcare workers in Srinagar, India. Influenza Other Respir Viruses 2013;7:540-5. [CrossRef]

22. Santaularia J, Hou W, Perveen G, Welsh E, Faseru B. Prevalence of influenza vaccination and its association with health conditions and risk factors among Kansas adults in 2013: a crosssectional study. BMC Public Health 2016;16:185. [CrossRef] 